\title{
A metric space approach to the information channel capacity of spike trains
}

\author{
James B Gillespie*, Conor J Houghton \\ From Twentieth Annual Computational Neuroscience Meeting: CNS*2011 \\ Stockholm, Sweden. 23-28 July 2011
}

\begin{abstract}
A novel method is presented for calculating the information channel capacity of spike trains. This method works by fitting a $\chi$-distribution to the distribution of distances between responses to the same stimulus: the $\chi$-distribution is the length distribution for a vector of Gaussian variables. The dimension of this vector defines an effective dimension for the noise and by rephrasing the problem in terms of distance based quantities, this allows the channel capacity to be calculated. As an example, the capacity is calculated for a data set recorded from auditory neurons in zebra finch.
\end{abstract}

\section{Acknowledgements}

JBG wishes to thank the Irish Research Council of Science, Engineering and Technology for an Embark Postgraduate Research Scholarship. CJH wishes to thank Science Foundation Ireland for Research Frontiers Programme grant 08/RFP/MTH1280.

Published: 18 July 2011

Submit your next manuscript to BioMed Central and take full advantage of:

- Convenient online submission

- Thorough peer review

- No space constraints or color figure charges

- Immediate publication on acceptance

- Inclusion in PubMed, CAS, Scopus and Google Scholar

- Research which is freely available for redistribution

\section{() Biomed Central}

